\title{
Perbedaan Efek Daya Hambat Jus Kulit Buah Manggis dengan Air Rebusan Kulit Buah Manggis sebagai Antibakteri terhadap Bakteri Gram-Positif (Staphylococcus aureus dan Streptococcus pyogenes) secara In Vitro
}

\author{
Nani Hendriani ${ }^{1}$, Netti Suharti ${ }^{2}$, Julizar ${ }^{3}$
}

\begin{abstract}
Abstrak
Bakteri Gram-positif seperti Staphylococcus aureus dan Streptococcus pyogenes telah resisten terhadap beberapa antibiotik, sehingga perlu dicari antibakteri alternatif lain. Manggis merupakan salah satu tanaman obat tradisional yang telah lama digunakan sebagai antibakteri. Penelitian ini dilakukan secara eksperimental terhadap kedua bakteri tersebut, yang diberi enam perlakuan dengan enam kali pengulangan, yaitu kontrol positif (amoksisilin $25 \mathrm{mcg}$ ), kontrol negatif (larutan aquades), jus kulit buah manggis dosis I (konsentrasi 58,3\% v/v) dan dosis II (konsentrasi 29,15\% v/v), serta air rebusan kulit buah manggis dosis I (konsentrasi 30,7\% v/v) dan dosis II (konsentrasi $15,35 \% \mathrm{v} / \mathrm{v}$ ). Cawan petri dengan kedua isolat bakteri yang telah ditanami cakram dengan 6 perlakuan diinkubasi selama 24 jam pada suhu $37^{\circ} \mathrm{C}$, kemudian diukur diameter halo yang dihasilkan. Hasil penelitian menunjukkan bahwa air rebusan kulit buah manggis memiliki efek daya hambat yang lebih baik daripada jus kulit buah manggis. Efek antibakteri jus dan air rebusan kulit buah manggis lebih sensitif pada bakteri Staphylococcus aureus dibanding bakteri Streptococcus pyogenes.
\end{abstract}

Kata kunci: kulit buah manggis, jus, air rebusan, Staphylococcus aureus, Streptococcus pyogenes

\begin{abstract}
Gram-positive bacteria such as Staphylococcus aureus and Staphylococcus pyogenes have developed resistance to some antibiotic, therefore need to find another alternative as antibacterial. Mangosteen well known as one of the traditional medicine used as antibacterial. This study was conducted in experimental fashion toward both of those bacteria which was given 6 treatment with 6 times repetition, consist of positive control (25 mcg of amoxicillin), negative control (aquades solution), mangosteen pericarp juice dose I (58\% v/v) and dose II (29,15\% v/v), and boiled mengosteen pericarp dose I (30,7\% v/v) and dose II (15,35\% v/v). Six paper disks treated with before mentioned treatment was putted on a petri dish which previously has been isolated with both of those bacteria incubated for 24 hour at temperature of $37^{\circ}$ celcius. The halo produced after incubation period was measured. The result showed that boiled mangosteen pericarp has better inhibitory effect compared to mangosteen pericarp juice. Both antibacterial effect were more sensitive on Staphylococcus aureus than Streptococcus pyogenes.
\end{abstract}

Keywords: mangosteen pericarp, juice, boiled, Staphylococcus aureus, Streptococcus pyogenes

Affiliasi penulis: 1. Pendidikan Dokter FK UNAND (Fakultas Kedokteran Universitas Andalas Padang), 2. Bagian Mikrobiologi FK UNAND, 3, Bagian Fisika FK UNAND.

Korespondensi: Nani Hendriani, email: nani_hendriani@yahoo.com Telp: 082170171404

\section{PENDAHULUAN}

Kejadian penyakit infeksi masih menjadi masalah kesehatan yang tinggi baik di negara maju maupun negara berkembang. Berdasarkan Profil Kesehatan Indonesia tahun 2009, penyakit infeksi dan parasit tertentu menempati urutan ke-2 dalam 10 
penyakit utama penyebab kematian di rumah sakit. Menurut Daftar Tabulasi Dasar (DTD), dari 10 penyakit terbanyak pada pasien rawat jalan di rumah sakit tahun 2009 menunjukkan bahwa kasus terbanyak adalah penyakit infeksi saluran napas bagian atas dengan jumlah total kasus $488.794{ }^{1}$

Bakteri merupakan salah satu penyebab infeksi, baik bakteri Gram-positif maupun Gramnegatif. Contoh bakteri Gram-positif adalah Staphylococcus aureus dan Streptococcus pyogenes. Staphylococcus aureus merupakan salah satu penyebab utama infeksi di rumah sakit dan masyarakat pada umumnya. ${ }^{2}$ Penyakit yang bisa ditimbulkan akibat infeksi Staphylococcus aureus, diantaranya endokarditis, osteomielitis hematogen akut, meningitis, infeksi paru. keracunan makanan, sindrom syok toksik, infeksi folikel rambut, serta kontaminasi langsung pada luka, seperti infeksi Staphylococcus aureus pada luka pascaoperasi. Infeksi oleh bakteri Streptococcus pyogenes dapat menimbulkan penyakit seperti faringitis, pioderma, endokarditis infektif, necrotizing fasciitis, miositis, sindrom syok toksik Streptococcus, demam scarlet hingga demam rematik dan glomerulonefritis. ${ }^{3}$

Dewasa ini, banyak bakteri yang telah mengalami resistensi terhadap beberapa antibiotik, diantaranya Staphylococcus aureus dan Streptococcus pyogenes. Bakteri S. aureus diketahui telah resisten terhadap beberapa antibiotik, seperti penisilin, oksasilin dan antibiotik beta laktam lainnya. Persentase galur $S$. aureus yang telah resisten terhadap metisilin (MRSA) cukup tinggi di Asia, seperti di Taiwan mencapai 60\%, Cina 20\%, Hong Kong 70\%, Filipina 5\%, dan Singapura 60\%. Di Asia, S. aureus yang resisten terhadap siprofloksasin mencapai $37 \%$. Streptococcus pyogenes juga sudah resisten terhadap eritromisin dan makrolid lainnya. ${ }^{5}$

Pengobatan penyakit infeksi yang disebabkan bakteri yang resisten terhadap antibiotik memerlukan produk baru yang memiliki potensi tinggi. Penelitian zat berkhasiat sebagai antibakteri perlu dilakukan untuk menemukan produk antibiotik baru yang berpotensi untuk menghambat atau membunuh bakteri yang resisten terhadap antibiotik tertentu dengan harga yang terjangkau. Salah satu alternatif yang dapat ditempuh adalah dengan memanfaatkan zat aktif pembunuh bakteri yang terkandung dalam tanaman obat. Salah satu tanaman yang mempunyai daya antibakteri adalah kulit buah manggis (Garcinia mangostana). ${ }^{6}$

Berbagai hasil penelitian menunjukkan kulit buah manggis kaya akan antioksidan, terutama antosianin, xanthone, tannin, dan asam fenolat. Kulit buah manggis mengandung xanthone sebagai antioksidan, antibakteri, antitumor dan antikanker. ${ }^{7}$

Berdasarkan penelitian yang dilakukan oleh Poeloengan dan Praptiwi (2010) mengenai uji aktivitas antibakteri ekstrak kulit buah manggis terhadap 2 isolat bakteri Gram-positif, yaitu Staphylococcus aureus dan Staphylococcus epidermidis dan dua isolat bakteri Gram-negatif, yaitu Escherichia coli dan Salmonella typhirium didapatkan hasil bahwa ekstrak kulit buah manggis membentuk zona penghambatan pertumbuhan yang absolut pada bakteri Gram-positif yang diuji, namun pada bakteri Gram-negatif hanya terjadi zona penghambatan pertumbuhan parsial. ${ }^{8}$

\section{METODE}

Jenis penelitian adalah eksperimental dengan enam kali pengulangan menggunakan desain post test only control group design. Sebagai sampel dari penelitian ini digunakan buah manggis yang berwarna merah cerah hingga merah keunguan, daging buah berwarna putih, kulit buah tidak cacat, berdiameter 55$65 \mathrm{~mm}$, yang diperoleh dari Kecamatan Kuranji Kota Padang, dengan jarak pengambilan buah hingga buah diolah sekitar 24-48 jam. Penelitian dilaksanakan pada bulan Desember 2013 di Laboratorium Mikrobiologi Fakultas Kedokteran Universitas Andalas.

Variabel dependen penelitian adalah daya hambat yang dihasilkan pada isolat bakteri Staphylococus aureus dan Streptococcus pyogenes dalam cm. Alat yang digunakan untuk mengukur diameter daya hambat adalah mistar dengan ketelitian $0,1 \mathrm{~cm}$. Variabel independen adalah jus kulit buah manggis konsentrasi $29,15 \%$ dan $58,3 \%$ dan air rebusan kulit buah manggis konsentrasi 15,35\% dan konsentrasi $30,7 \%$ yang dikonversi ke skala ordinal sehingga jus kulit buah manggis konsentrasi $29,15 \%$ menjadi jus dosis II, jus kulit buah manggis konsentrasi 58,3\% menjadi jus dosis I, air rebusan kulit buah manggis konsentrasi $15,35 \%$ menjadi AR 
dosis II, dan air rebusn kulit buah manggis konsentrasi $30,7 \%$ menjadi AR dosis I. Alat yang digunakan adalah cawan petri, tabung reaksi, kertas saring, pelubang kertas, lem, jarum ose, lampu spiritus, pinset, gelas ukur, otoklaf, incubator, spuit dispossible, lidi kapas steril, mistar, pisau, talenan, dan sendok. Bahan yang digunakan adalah jus kulit buah manggis, air rebusan kulit buah manggis, biakan murni Staphylococcus aureus dan Streptococcus pyogenes, agar darah dan agar Mueller Hinton II, aquades steril, $\mathrm{NaCl}$ 0,9\%, serta alkohol 70\%.

HASIL

Tabel 1. Nilai rerata pengukuran daya hambat jus kulit buah manggis dan air rebusan kulit buah manggis terhadap bakteri Staphylococcus aureus dan Streptococcus pyogenes secara in vitro

\begin{tabular}{lccc}
\hline Perlakuan & N & $\begin{array}{c}\text { Rerata } \pm \text { SD } \\
\text { (Staphylococcu } \\
\text { s aureus) }\end{array}$ & $\begin{array}{c}\text { Rerata } \pm \text { SD } \\
\text { (Streptococcus } \\
\text { pyogenes) }\end{array}$ \\
\hline Kontrol Positif & 6 & $1,7 \pm 0,0632$ & $4,1 \pm 0,2191$ \\
Kontrol Negatif & 6 & 0 & 0 \\
Jus dosis I & 6 & $0,917 \pm 0,0408$ & 0 \\
Jus dosis II & 6 & $0,883 \pm 0,753$ & 0 \\
AR dosis I & 6 & $1,05 \pm 0,1517$ & $0,667 \pm 0,3266$ \\
AR dosis II & 6 & $0,933 \pm 0,1211$ & $0,383 \pm 0,4262$ \\
\hline
\end{tabular}

Tabel 1 memperlihatkan bahwa pemberian jus dan air rebusan kulit buah manggis dengan konsentrasi berbeda memiliki daya hambat yang berbeda pula terhadap pertumbuhan bakteri Staphylococcus aureus dan Streptococcus pyogenes. Perbedaan ini selanjutnya diuji dengan pengukuran statistik secara komputerisasi. Berhubung data hasil penelitian yang didapatkan tidak memenuhi syarat uji Anova dua arah karena tidak terdistribusi normal, maka pengolahan data dilanjutkan dengan KruskalWallis Test. Hasil Kruskal-Wallis Test didapatkan hasil bahwa terdapat perbedaan bermakna antar perlakuan dari masing-masing bakteri.

Perlakuan yang memiliki perbedaan dilanjutkan dengan Mann-Whitney Test. Hasil dapat dilihat pada Tabel 2. Pada uji Mann-Whitney, jika didapatkan nilai $\mathrm{P}<0,05$ berarti ditemukan perbedaan yang bermakna antara dua kelompok yang dibandingkan.
Tabel 2. Nilai $p$ uji Mann Whitney pada pengukuran daya hambat pada bakteri Staphylococcus aureus

\begin{tabular}{lccccc}
\hline Perlakuan & $\begin{array}{c}\text { Kontrol } \\
(+)\end{array}$ & $\begin{array}{c}\text { Jus } \\
\text { dosis } \\
\text { I }\end{array}$ & $\begin{array}{c}\text { Jus } \\
\text { dosis } \\
\text { II }\end{array}$ & $\begin{array}{c}\text { AR } \\
\text { dosis } \\
\text { I }\end{array}$ & $\begin{array}{c}\text { AR } \\
\text { dosis } \\
\text { II }\end{array}$ \\
\hline Kontrol (+) & - & 0,002 & 0,003 & 0,003 & 0,003 \\
Jus dosis I & 0,002 & - & 0,338 & 0,065 & 0,796 \\
Jus dosis II & 0,003 & 0,338 & - & 0,049 & 0,452 \\
AR dosis I & 0,003 & 0,065 & 0,049 & - & 0,161 \\
AR dosis II & 0,003 & 0,796 & 0,452 & 0,161 & - \\
\hline
\end{tabular}

Tabel 2. yang memiliki perbedaan bermakna adalah kontrol positif dengan perlakuan jus dan air rebusan baik dosis I maupun dosis II, serta jus dosis II dengan air rebusan dosis I, sedangkan yang tidak berbeda bermakna adalah jus dosis I dengan jus dosis II, jus dosis I dengan air rebusan dosis I, jus dosis I dengan air rebusan dosis II, jus dosis II dengan air rebusan dosis II dan air rebusan dosis I dengan air rebusan dosis II.

Tabel 3. Nilai $\mathrm{p}$ uji Mann Whitney pada pengukuran daya hambat pada bakteri Streptococcus pyogenes

\begin{tabular}{lccccc}
\hline Perlakuan & $\begin{array}{c}\text { Kontrol } \\
(+)\end{array}$ & $\begin{array}{c}\text { Jus } \\
\text { dosis }\end{array}$ & $\begin{array}{c}\text { Jus } \\
\text { dosis }\end{array}$ & $\begin{array}{c}\text { AR } \\
\text { dosis }\end{array}$ & $\begin{array}{c}\text { AR } \\
\text { dosis }\end{array}$ \\
& & I & II & II \\
\hline Kontrol (+) & - & 0,002 & 0,002 & 0,003 & 0,003 \\
Jus dosis I & 0,002 & - & 1,000 & 0,005 & 0,058 \\
Jus dosis II & 0,002 & 1,000 & - & 0,005 & 0,058 \\
AR dosis I & 0,003 & 0,005 & 0,005 & - & 0,149 \\
AR dosis II & 0,003 & 0,058 & 0,058 & 0,149 & - \\
\hline
\end{tabular}

Pada Tabel 3 terlihat yang berbeda bermakna adalah kontrol positif dengan jus dan air rebusan baik dosis I maupun dosis II, jus dosis I dengan air rebusan dosis I dan jus dosis II dengan air rebusan dosis I, sedangkan yang tidak berbeda bermakna adalah jus dosis I dengan jus dosis II, jus dosis I dengan air rebusan dosis II, jus dosis II dengan air rebusan dosis II dan air rebusan dosis I dengan air rebusan dosis II.

\section{PEMBAHASAN}

Jus maupun air rebusan kulit buah manggis sama-sama memberikan efek daya hambat terhadap pertumbuhan bakteri Staphylococcus aureus, sedangkan percobaan dengan bakteri Streptococcus 
pyogenes hanya air rebusan saja yang memberikan efek daya hambat. Hasil penelitian ini sama dengan yang didapatkan oleh Priya et al (2010) serta Bhat dan Al-Daihan (2013), yaitu ekstrak kulit buah manggis sama-sama mempunyai efek antibakteri terhadap Staphylococcus aureus dan Streptococcus pyogenes. $^{9,10}$ Penelitian yang dilakukan oleh Chitchumroonchokchai et al (2012) terhadap beberapa produk olahan jus kulit buah manggis yang dijual di pasaran menunjukkan bahwa jus tersebut memiliki efek antibakteri. ${ }^{11}$

Dari hasil penelitian ini juga dapat disimpulkan bahwa air rebusan kulit buah manggis memiliki efek daya hambat lebih baik terhadap kedua bakteri daripada jus kulit buah manggis. Hal ini mungkin terjadi karena air rebusan termasuk salah satu metode ekstraksi yang disebut dengan infusa. Infusa merupakan sediaan cair yang dibuat dengan cara mengekstrak bahan nabati dengan air pada suhu $90^{\circ} \mathrm{C}$ selama 10-15 menit yang dihitung sejak air mendidih. ${ }^{12}$ Sedangkan pada jus hanya terjadi proses penghancuran dan panghalusan dengan blender.

Berefeknya kulit buah manggis sebagai antibakteri dimungkinkan karena kulit buah manggis mengandung banyak jenis antioksidan, diantaranya xanthone. Xanthone merupakan suatu bahan kimia aktif dengan titik leleh $173^{\circ} \mathrm{C}$ sampai dengan $176^{\circ} \mathrm{C}$. Oleh karena itu, xanthone dalam buah manggis tidak akan hilang kalau buah itu dimasak atau dipanaskan dibawah suhu tersebut. Xanthone memiliki banyak khasiat diantaranya sebagai antibakteri. ${ }^{13}$

\section{KESIMPULAN}

Pemberian jus kulit buah manggis memiliki efek daya hambat terhadap pertumbuhan bakteri Staphylococcus aureus. Pemberian jus kulit buah manggis tidak memiliki efek daya hambat terhadap pertumbuhan bakteri Streptococcus pyogenes. Pemberian air rebusan kulit buah manggis memiliki efek daya hambat terhadap pertumbuhan bakteri Staphylococcus aureus. Pemberian air rebusan kulit buah manggis memiliki efek daya hambat terhadap pertumbuhan bakteri Streptococcus pyogenes.

Terdapat perbedaan efek daya hambat jus dengan air rebusan kulit buah manggis pada bakteri yang sama (Staphylococcus aureus dan
Streptococcus pyogenes), dimana secara statistik yang ditemukan berbeda bermakna pada bakteri Staphylococcus aureus yaitu pada perlakuan jus dosis II dengan air rebusan dosis I, sedangkan pada bakteri Streptococcus pyogenes yang ditemukan berbeda bermakna adalah pada perlakuan jus dosis I dengan air rebusan dosis I serta jus dosis II dengan air rebusan dosis 1 .

\section{DAFTAR PUSTAKA}

1. Kementerian Kesehatan Republik Indonesia. Profil kesehatan Indonesia tahun 2009. Jakarta: 2010.

2. Naimi TS, LeDell KH, Como-Sabetti K., Borchardt SM, Boxrud DJ, Etienne J, et al. Comparison of community and health care-associated methicillinresistant staphylococcus aureus infection. The Journal of the American Medical Association. 2003; 290(22): 2976-84

3. Jawetz E, Melnick JL, Adelberg EA. Mikrobiologi Kedokteran (terjemahan). Edisi ke-24. Jakarta: EGC; 2007.

4. Bell JM, Turnidge JD. Participants. high prevalence of oxacillin-resistant staphylococcus aureus isolates from hospitalized patients in Asia-Pacific and South Africa: Results from SENTRY Antimicrobial Surveillance Program, 1998-1999. Antimicrobial Agents And Chemotherapy. 2002; 46(3).

5. Schito GC. Clinical microbiology and infection. Italy: European Society of Clinical Microbiology and Infectious Diseases. 2002; 8(3):1-8.

6. Mardiana L. Ramuan dan khasiat kulit buah manggis. Jakarta: Penebar Swadaya; 2013.

7. Yunitasari L. Gempur 41 penyakit dengan buah manggis, khasiat dan cara pengolahannya untuk pengobatan. Yogyakarta: Pustaka Baru Press; 2011.

8. Poeloengan M, Praptiwi. Uji aktivitas antibakteri ekstrak kulit buah manggis (garcinia mangostana linn). Media Litbang Kesehatan. 2010; 20(2).

9. Priya V, Jainu M, Mohan SK, Saraswathi, Gopan CS. Antimicrobial activity of pericarp extract of Garcinia Mangostana Linn. India: International Journal of Pharma Sciences and Research (IJPSR). 2010;1(8). 
10. Bhat RS, Al-Daihan S. Antimicrobial activity of garcinia mangostana using different solvents extracts. International Journal of Biosciences. 2013;3(10):267-72.

11. Chitchumroonchokchai C, Riedl KM, Suksumrarn S, Clinton SK, Kinghorn AD, Failla ML. Xanthones in mangosteen juice are absorbed and partially conjugated by healthy adults. The Journal of Nutrition. 2012; 675-80.

12. Suranto A. Khasiat dan manfaat madu herbal. Jakarta: AgroMedia Pustaka; 2004.

13. Iswari K. Kulit manggis berkhasiat tinggi. Jakarta: APMK Madya Centradifa; 2011. 